\title{
NT-proBNP predicts the need for ventilatory support in the patients with acute exacerbation of chronic obstructive pulmonary disease
}

\author{
J Kuharic ${ }^{*}$, A Sustic $^{1}$, R Marcun ${ }^{2}$, M Lainscak $^{3}$ \\ From ESICM LIVES 2015 \\ Berlin, Germany. 3-7 October 2015
}

\section{Introduction}

Patients with acute exacerbation of chronic obstructive pulmonary disease (AECOPD) may need ventilatory support (VS) due to respiratory failure. Risk stratification on admission could identify patients at higher risk of deterioration. Cardiac biomarkers are associated with outcome in AECOPD but were not studied as predictors for VS.

\section{Objectives}

The aim of this study was to evaluate association between admission NT-proBNP and ventilatory support (VS) in the patients with AECOPD.

\section{Methods}

The prospective observational study included 139 patients with a clinical diagnosis of AECOPD and Global Initiative for Chronic Obstructive Lung Disease (GOLD) stages III-IV. NT-proBNP was determined from venous blood samples on patient admissions to the hospital with the use of a quantitative electrochemiluminescence assay on an Elecsys 2010 analyzer (Roche Diagnostics) according to established methods. The VS was defined as any form of invasive or noninvasive VS applied during index hospital stay.

\section{Results}

Patients who did not require (no.:108) vs. those who required VS (no.:31) and patients with invasive (no.:15) vs. those with noninvasive VS (no.:16) were of similar age, gender and GOLD stage ( $p>0.2$ for all). NT-proBNP was higher in patients who required VS

${ }^{1}$ Univ. Hospital Rijeka, Dept. of Anesthesiology and ICU, Rijeka, Croatia Full list of author information is available at the end of the article then in those without VS $(2407 \pm 3431$ vs. $1709 \pm 4648$ $\mathrm{ng} / \mathrm{L} ; \mathrm{p}<0.05)$. Patients with noninvasive VS had higher NT-proBNP then those without VS $(3213 \pm 4389$ vs.1709 $\pm 4648 \mathrm{ng} / \mathrm{L} ; \mathrm{p}<0.05)$. The difference between patients treated with noninvasive vs. invasive VS was not significant $(3213 \pm 4389$ vs. $1534 \pm 1753 \mathrm{ng} / \mathrm{L}$; $\mathrm{p}=\mathrm{NS})$. Patients receiving invasive VS had similar admission NT-proBNP as those without VS $(1534 \pm 1753$ vs. $1709 \pm 4648 \mathrm{ng} / \mathrm{L} ; \mathrm{p}=\mathrm{NS}$ ).

\section{Conclusions}

Admission NT-proBNP may predict need for noninvasive VS in patients with AECOPD.

\section{Authors' details}

${ }^{1}$ Univ. Hospital Rijeka, Dept. of Anesthesiology and ICU, Rijeka, Croatia. ${ }^{2}$ University Clinic of Respiratory Diseases, Dept. of Pneumology, Golnik, Slovenia. ${ }^{3}$ General Hospital Celje, Dept. of Cardiology, Celje, Slovenia.

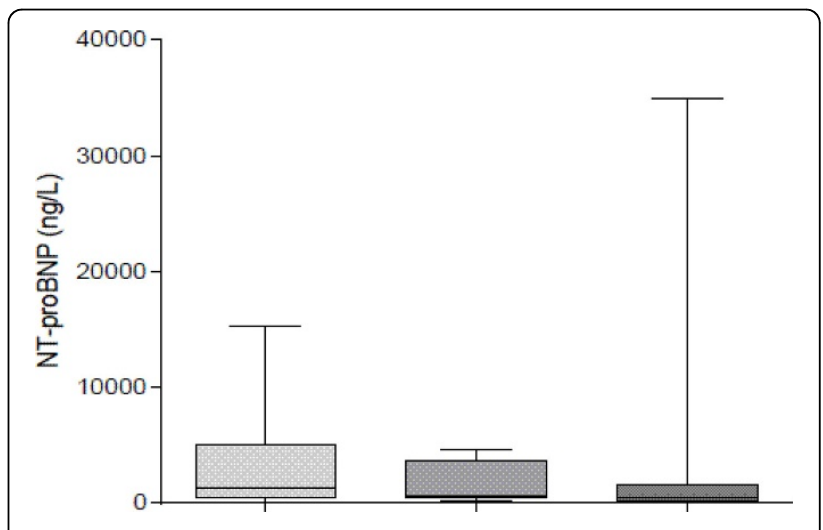

Figure 1 Relation between NT-proBNP and ventilation.

(c) 2015 Kuharic et al.; This is an Open Access article distributed under the terms of the Creative Commons Attribution License (http:// creativecommons.org/licenses/by/4.0), which permits unrestricted use, distribution, and reproduction in any medium, provided the original work is properly cited. 


\section{Reference}

1. Marčun R, et al: Int J Cardiol 2012, 161:156-159.

doi:10.1186/2197-425X-3-S1-A390

Cite this article as: Kuharic et al:: NT-proBNP predicts the need for

ventilatory support in the patients with acute exacerbation of chronic obstructive pulmonary disease. Intensive Care Medicine Experimental 2015

3(Suppl 1):A390.

\section{Submit your manuscript to a SpringerOpen ${ }^{\circ}$ journal and benefit from:}

- Convenient online submission

- Rigorous peer review

- Immediate publication on acceptance

- Open access: articles freely available online

- High visibility within the field

- Retaining the copyright to your article

Submit your next manuscript at $\gg$ springeropen.com 